\title{
Vývoj československého práva 1945-1989, red. J. Kuklík, Wyd. Linde, Praha 2009, 727 stron.
}

Mijające właśnie dwadzieścia lat od upadku reżimów komunistycznych unaocznia, jak coraz bardziej odległy staje się dla nas czas istnienia państw bloku socjalistycznego. Tym ważniejszym problemem staje się nauczanie historii prawa minionego okresu. Zapotrzebowaniu temu wyszedł naprzeciw w Czechach 10-osobowy zespół autorski pod kierownictwem profesora Jana Kuklíka z Uniwersytetu Karola w Pradze. Redaktor podręcznika jest znanym specjalistą z zakresu najnowszej historii prawa i autorem pracy o dekretach Beneša ${ }^{1}$. Warto zwrócić uwagę, że podręcznik powstał po dziewięciu latach od wydania polskiego odpowiednika ${ }^{2}$, co skłania do zadania pytania o przyczyny tego stanu rzeczy. W krótkim wstępie redaktor książki podkreśla, że jest ona w dużej części rezultatem grantu, dzięki któremu w 2004 r. powstała obszerna praca zbiorowa o stanie badań nad prawem komunistycznej Czechosłowacji ${ }^{3}$. Bez niej, zdaniem redaktora, nie byłoby możliwe przystąpienie do pisania syntezy, jaką jest recenzowany podręcznik.

Naszą uwagę zwraca przede wszystkim objętość publikacji - ponad 700 stron tekstu. Wprawdzie część pracy to dokumenty archiwalne ilustrujące praktykę funkcjonowania prawa czechosłowackiego (akty prawne, wyroki, decyzje administracyjne, protokoły posiedzeń, instrukcje itp.), ale stanowią one tylko około $10 \%$ tekstu. Na pozostałe ponad 600 stron składają się opisy poszczególnych instytucji socjalistycznego prawa. Nie orientuję się, jak obszerny godzinowo jest wykład historii prawa czeskiego, ale wydaje się, że sam podręcznik swoją treścią mógłby dostarczyć materiału dydaktycznego na cały rok studiów. Powstaje więc pytanie o rzeczywistych adresatów podręcznika: czy są nimi studenci pierwszego roku studiów, czy też ma być on wprowadzeniem do prac seminaryjnych? Wydaje się, że jest on adresowany do rozpoczynających edukację prawniczą studentów - o czym świadczą zamieszczone przykłady z praktyki. Czy jednak student będzie w stanie opanować tak obszerny materiał? Jako historyk prawa doceniam oczywiście zalety poznawcze obszerniejszej pracy oraz pomysł prezentacji dokumentów z praktyki, wyrażam jedynie wątpliwość co do możliwości przedstawienia całości w ramach wykładu kursowego.

Układ podręcznika jest niejednolity, został podzielony na 20 rozdziałów. W początkowej części zastosowano kryterium chronologiczne. Odnosi się to głównie do historii ustroju i prawa karnego - rozdziały I-VIII (dlaczego tak?); pozostałe rozdziały to mniej

1 J. Kuklík, Mýty a realita tzv. Benešových dekretů, Praha 2002.

2 M. Kallas, A. Lityński, Historia ustroju i prawa Polski Ludowej, Warszawa 2000.

3 Vývoj práva v Československu v letech 1945-1989. Sborník př́spěvků, red. K. Malý i L. Soukup, Praha 2004. Zob. w polskiej literaturze artykuł recenzyjny: P. Fiedorczyk, O dziejach prawa $w$ socjalistycznej Czechosłowacji, „Czasopismo Prawno-Historyczne” 2006, t. LVIII, z. 2, s. 321-331. 
lub bardziej obszerne syntezy poszczególnych gałęzi prawa. Przykładowo - rozdział o prawie rodzinnym w czasach komunistycznych zajmuje 4 strony, tyleż samo co rozdział o postępowaniu cywilnym (!). Z kolei rozdział o organizacji sądownictwa i prokuratury to aż 71 stron, $w$ dodatku podzielonych na część przedstawiającą przepisy oraz na tzw. część analityczną, prezentującą poszczególne problemy sądownictwa: niezawisłość („w praktyce i na papierze”), stosowanie prawa oraz hierarchiczną organizację. Równie obszerne (co zrozumiałe) są dwa rozdziały o prawie cywilnym (pierwszy z nich przedstawia periodyzację dziejów tej gałęzi i zagadnienia ogólne, natomiast drugi opisuje poszczególne działy prawa cywilnego). Osobne rozdziały poświęcono pozycji prawnej mniejszości narodowych, cenzurze, prawu zabezpieczenia społecznego, prawu gospodarczemu, prawu pracy oraz prawu rolnemu. Zwraca także uwagę ostatni rozdział książki o marksistowsko-leninowskiej teorii prawa w Czechosłowacji. Przypuszczać należy, iż opisany powyżej nie do końca spójny układ pracy ma swoje źródło w nierównym stanie zaawansowania badań nad poszczególnymi gałęziami prawa socjalistycznej Czechosłowacji. Uderza pominięcie (poza niewielkimi wzmiankami) problemów procedury karnej, jednej z tych gałęzi prawa, które decydowały o totalitarnym kształcie państwa.

Podkreślić należy podstawową zaletę przedstawionej książki. Autorzy starają się konsekwentnie przedstawić praktykę funkcjonowania prawa w socjalizmie i wykazać jego fasadowość oraz zakłamanie rzeczywistości. Jest to bardzo ważne, gdyż po 20 latach od upadku komunizmu obecna młodzież, nieznająca realiów starego ustroju, skłonna jest przyjmować za dobrą monetę „socjalistyczne” rozwiązania prawne. Lektura podręcznika pozbawia tych złudzeń. Problem tylko w tym, czy student da radę „przebrnąć" przez tak obszerną pracę.

Ukazanie się prezentowanej książki należy uznać za ważne wydarzenie w badaniach nad prawem komunistycznej Czechosłowacji. Pozwala ono na konstatację o postępie badań w stosunku do roku 2004. Ciągle jednak istnieją dziedziny nie eksplorowane naukowo (np. prawo rodzinne). Jest to zresztą całkiem naturalne, zważywszy na ogromny potencjalny zakres badań. 